Article

\title{
Experimental Investigation on the Effect of Phase Change Materials on Compressed Air Expansion in CAES Plants
}

\author{
Beatrice Castellani *, Andrea Presciutti ${ }^{\dagger}$, Mirko Filipponi ${ }^{\dagger}$, Andrea Nicolini ${ }^{\dagger}$ and Federico Rossi \\ CIRIAF, University of Perugia, Via G. Duranti 67, 06125 Perugia, Italy; \\ E-Mails: andrea.presciutti@unipg.it (A.P.); mirko.filipponi@unipg.it (M.F.); \\ andrea.nicolini@unipg.it (A.N.); federico.rossi@unipg.it (F.R.)
}

$\dagger$ These authors contributed equally to this work.

* Author to whom correspondence should be addressed; E-Mail: beatrice.castellani@unipg.it; Tel.: +39-075-585-3853; Fax: +39-074-449-2985.

Academic Editors: Francesco Asdrubali, Pietro Buzzini and Marc A. Rosen

Received: 4 June 2015 / Accepted: 15 July 2015 / Published: 23 July 2015

\begin{abstract}
The integration of renewable energy in the electrical grid is challenging due to the intermittent and non-programmable generated electric power and to the transmission of peak power levels. Several energy storage technologies have been studied to find a solution to these issues. In particular, compressed air energy storage (CAES) plants work by pumping and storing air into a vessel or in an underground cavern; then when energy is needed, the pressurized air is expanded in an expansion turbine. Several CAES configurations have been proposed: diabatic, adiabatic and isothermal. The isothermal process seems to be the most promising to improve the overall efficiency. It differs from conventional CAES approaches as it employs near-isothermal compression and expansion. Currently, there are no commercial isothermal CAES implementations worldwide, but several methods are under investigation. In this paper, the use of phase change materials (PCM) for isothermal air expansion is discussed. Air expansion tests in presence of PCM were carried out in a high-pressure vessel in order to analyze the effect of PCM on the process. Results show that in presence of PCM near isothermal expansion conditions occur and therefore they affect positively the value of the obtainable expansion work.
\end{abstract}

Keywords: energy storage; CAES; phase change materials; isothermal air expansion 


\section{Introduction}

During the last decade, energy policies and strategies have been mainly addressed to increase the diffusion of renewable energy technologies, sustaining the shift from fossil to renewable energy sources and therefore the reduction of anthropogenic $\mathrm{CO}_{2}$ emissions.

A number of challenges and technical aspects need to be overcome to increase and manage the share of renewable energy in the existing electricity network. They are related to the intermittency and non-programmability of the renewable sources that create a mismatch between the electricity production and the corresponding occurrence of load demand [1].

In addition, while solar and wind power have seen a large expansion, the existing electricity network remains largely unchanged. This has left the current electrical energy system un-optimized and in need of adjustments. The electricity transmission system needs to be adapted to smaller local energy production sites instead of the larger scale production sites used today. Energy storage solutions need to be implemented to compensate for the fluctuations in intermittent energy production [2-6].

There is a wide range of different technologies to store electrical energy. A widely-used approach for classifying such systems is the determination according to the form of energy used. In particular, energy storage systems are classified into mechanical, electrochemical, chemical, electrical and thermal energy storage systems [7].

The most common mechanical storage systems are pumped hydroelectric power plants, compressed air energy storage (CAES) and flywheel energy storage. Electrochemical storage systems consist of various types of batteries (lead acid, $\mathrm{NiCd} / \mathrm{NiMH}, \mathrm{Li}$-ion, metal air, sodium sulfur, sodium nickel chloride and flow battery). Chemical energy storage focuses on hydrogen and synthetic natural gas (SNG) as secondary energy carriers and, finally, electrical storage systems include double-layer capacitors and superconducting magnetic energy storage [8-14].

Pumped hydro storage (PHS) and CAES are the only storage technologies available for high power ranges and energy capacities [15].

CAES plants work by pumping and storing air into a vessel or in an underground cavern when excess or low-cost electricity is available. Then when energy is needed, the pressurized air is expanded in an expansion turbine.

Several CAES configurations have been proposed: diabatic, adiabatic and isothermal. In the diabatic CAES, heat released during compression is dissipated by cooling and not stored, therefore air must be reheated prior to expansion in the turbine through fuel combustion.

Today only two diabatic CAES power plants are in operation worldwide. The first was built in 1978 in Huntorf, Germany. It works with a round-trip efficiency of roughly $41 \%$ [16]. It consists of a two-stage compressor with intercooler, two salt caverns each one with a usable volume of $155,000 \mathrm{~m}^{3}$ with internal pressure in the range between 46 and 72 bar, a two-stage turbine and a motor-generator with a charging power of $60 \mathrm{MW}$ and a discharging power of $321 \mathrm{MW}$.

The second diabatic CAES plant is in McIntosh (Alabama, USA) and was commissioned in 1991. It has a net electrical output of $110 \mathrm{MW}$ and additionally a recuperator is used to recover heat from the exhaust at the outlet of the gas turbine. A higher round trip efficiency of 54\% is achieved.

Both systems use off-peak electricity for air compression and are operated for peak leveling on a daily basis [7]. 
To improve efficiency of diabatic CAES, other configurations have been proposed and worldwide other CAES plants are under development and construction. Among the improved or advanced CAES technological proposals, there is the adiabatic CAES. The key component of such systems is the heat exchanger. It absorbs heat from the high-temperature compressed air and save the thermal energy to reheat the air before expansion. Therefore, during expansion, there is no need of a combustion process for increasing air temperature before entering the turbine. The heat exchangers and the material for thermal energy storage may increase the cost of the overall system [16]. However, the round-trip efficiency is expected to be over $70 \%[17,18]$.

Adiabatic CAES technology is currently under development. In Germany, an adiabatic CAES plant is scheduled for demonstration in 2016. The plant is planned to have a storage capacity of $360 \mathrm{MWh}$ and a power output of $90 \mathrm{MW}$, with the aim of $70 \%$ cycle efficiency [19]. Thermal energy storage will be carried out in a heat-storage pressure vessel containing beds of stones or ceramic bricks.

A new emerging technology, which attempts to overcome the limits of diabatic and adiabatic CAES, is isothermal CAES. Isothermal CAES is an alternative CAES system that eliminates the need for fuel and high temperature thermal energy storage. It is aimed at achieving isothermal compression and expansion in situ, instead of employing numerous stages of compression and expansion. This allows improving efficiency and lower capital costs. Isothermal CAES requires continuous heat removal during compression and continuous heat addition during expansion by means of effective heat transfer.

Currently, there are no commercial isothermal CAES plants, but some solutions have been proposed. One is a two-stage, mixed-phase (water-in-air) heat-transfer process within pneumatic cylinders. During piston strokes, water is sprayed into the air-filled chamber of each cylinder, allowing heat to be transferred from water to air during expansion or from air to water during compression [20].

In this paper phase change materials (PCM) are used to carry out isothermal air expansion. PCM are storage media with a high latent heat storage. Latent heat is the energy exchanged in a phase change, during which there is no change of temperature. The use of PCM is proposed in order to control P-v curve during compression and expansion so that it can resemble an isotherm. The preliminary experimental investigation was carried out only for the expansion stage. The phase change of paraffin-based PCM has the effect of leveling the internal temperature profile during air expansion, getting close to isothermal conditions.

\section{Experimental Section}

The experimental apparatus consists of a high-pressure cylindrical AISI 304 stainless steel vessel with internal diameter of $200 \mathrm{~mm}$, an internal length of $800 \mathrm{~mm}$ and a total internal volume of $25 \mathrm{~L}$. It has been designed for pressure values up to 120 bar and provided with a safety valve.

Two side flanges are used to seal the vessel. One side flange has appropriate ports for access to the interior. The ports are used for inserting two temperature sensors and for air inlet and outlet. The temperature sensors are mineral insulated type $T$ thermocouples (accuracy class 1 ) that measure the temperature inside the vessel in the lower part and in the upper part. The gas inlet line is equipped with a pressure sensor, that is a digital piezo-resistive manometer (Kobold-accuracy class 0.5 ). 
Before entering the vessel, air is compressed by an air-cooled two-stage reciprocating compressor. The maximum outlet pressure is 30 bar with a flow rate of $4 \mathrm{Nm}^{3} / \mathrm{h}$. The scheme of the experimental apparatus is shown in Figure 1.

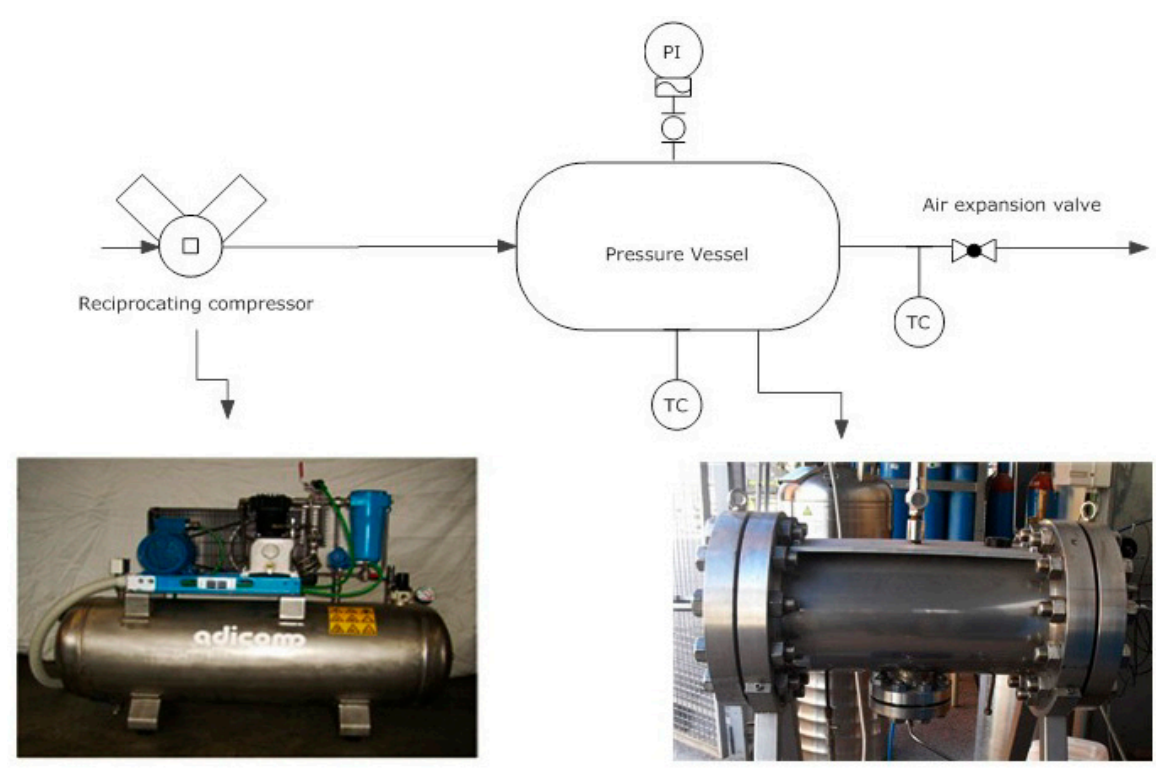

Figure 1. Schematic diagram of the experimental apparatus with the air compressor and high-pressure vessel.

The experimental procedure consists of the following steps:

- Air is compressed and uploaded in the vessel. Compression continues until an internal pressure of 20 bar or 30 bar is reached.

- Internal temperature and pressure are adjusted to reach the proper initial conditions

- The outlet port is opened to carry out air expansion. During this phase temperature and pressure are monitored.

Voltage signals from pressure transducers and temperature sensors are collected every two seconds by data acquisition software on a personal computer.

The phase change material tested in the present paper was supplied by Rubitherm Technologies $\mathrm{GmbH}$. The properties of the used PCM are summarized in Table 1.

Table 1. Properties of the used phase change material (PCM).

\begin{tabular}{cc}
\hline Properties & RT18HC \\
\hline Material & Paraffin \\
Melting Area $\left[{ }^{\circ} \mathrm{C}\right]$ & $17-19$ \\
Congealing area $\left[{ }^{\circ} \mathrm{C}\right]$ & $19-17$ \\
Heat storage capacity $[\mathrm{kJ} / \mathrm{kg}]$ & 250 \\
Specific heat capacity $[\mathrm{kJ} / \mathrm{kgK}]$ & 2 \\
Density solid $[\mathrm{kg} / \mathrm{L}]$ & 0.88 \\
Density liquid $[\mathrm{kg} / \mathrm{L}]$ & 0.77 \\
Heat conductivity $[\mathrm{W} / \mathrm{mK}]$ & 0.2 \\
Volume expansion $[\%]$ & 12 \\
\hline
\end{tabular}


Paraffin-based PCM is encapsulated in plastic discs and positioned inside the vessel to ensure an optimal interfacial area with internal air gas, as shown in Figure 2. Discs are assembled in packets of $0.28 \mathrm{~L}$. The thickness of PCM discs is about $5 \mathrm{~mm}$.

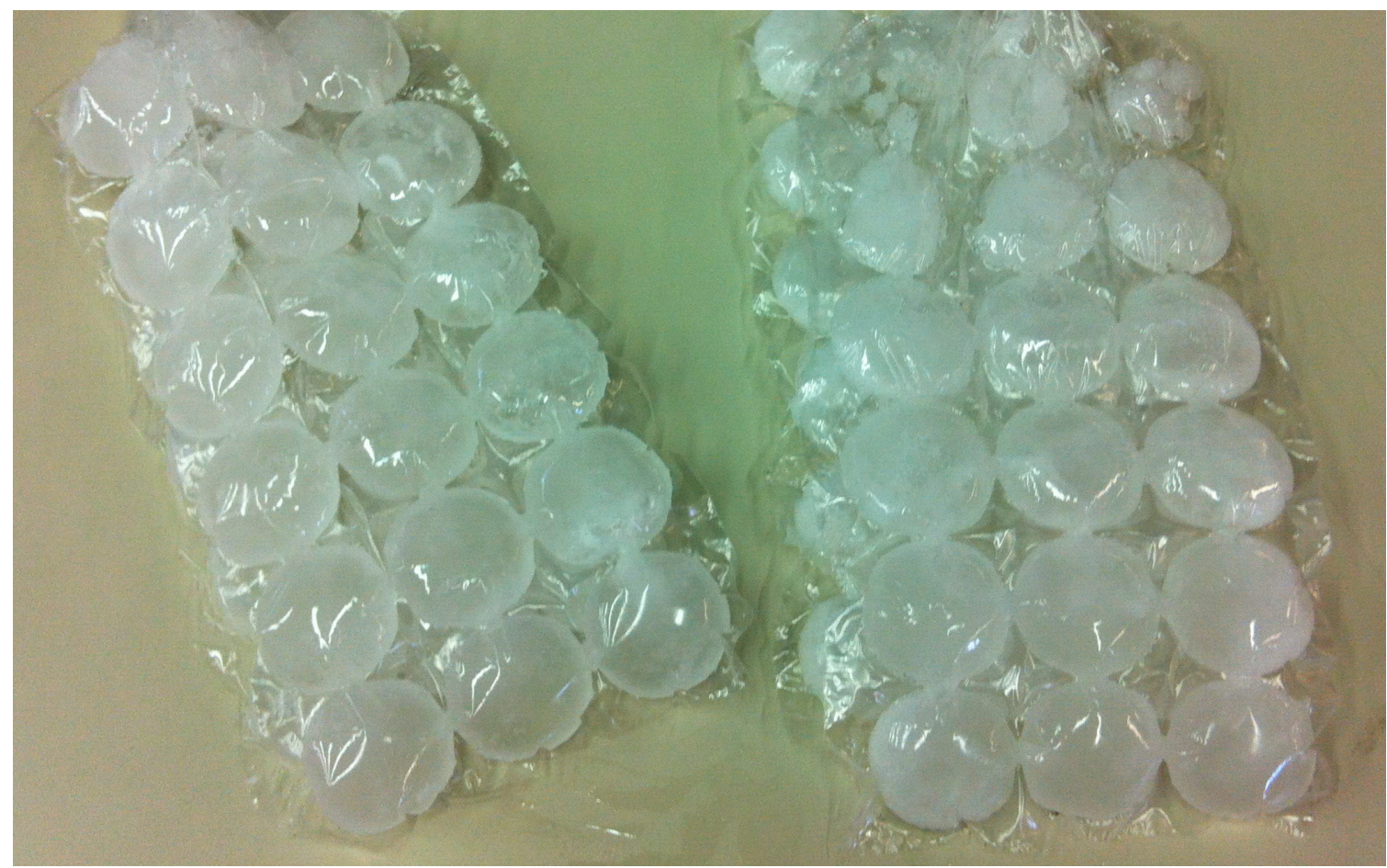

Figure 2. Paraffin-based phase change material (PCM) encapsulated in plastic discs.

\section{Objective of the Experimental Investigation}

Isothermal CAES aims at minimizing the compression work and maximizing the expansion work through isothermal compression and expansion by means of effective heat transfer. Energy and exergy flows of an isothermal CAES system for the production of $1 \mathrm{kWh}$ output were already evaluated by $[21]$.

The present experimental investigation has the objective of verifying the feasibility of PCM usage in isothermal CAES configurations and evaluating energy benefits. It supplies new experimental data on thermodynamic transformations in which air is expanded in presence of PCM. In this preliminary study no turbomachinery is used to recover expansion work. The high-pressure vessel in the experimental apparatus allows storing pressurized air after compression and contains right inside PCM packets. In absence of turbine, air expansion is carried out by opening the vessel's valve and downloading air in the environment. The effect of PCM on air thermodynamic transformations is evaluated by monitoring temperature and pressure values, which are used at a later stage for expansion work calculation. A further step of the research will be the addition of an air turbine in the experimental apparatus in which air expansion will be implemented and electrical energy will be produced. At that stage, the vessel will represent just the storage volume of the CAES system and PCM will be located inside the air turbine.

The scheme of isothermal CAES concept with temperature and pressure values is shown in Figure 3. 


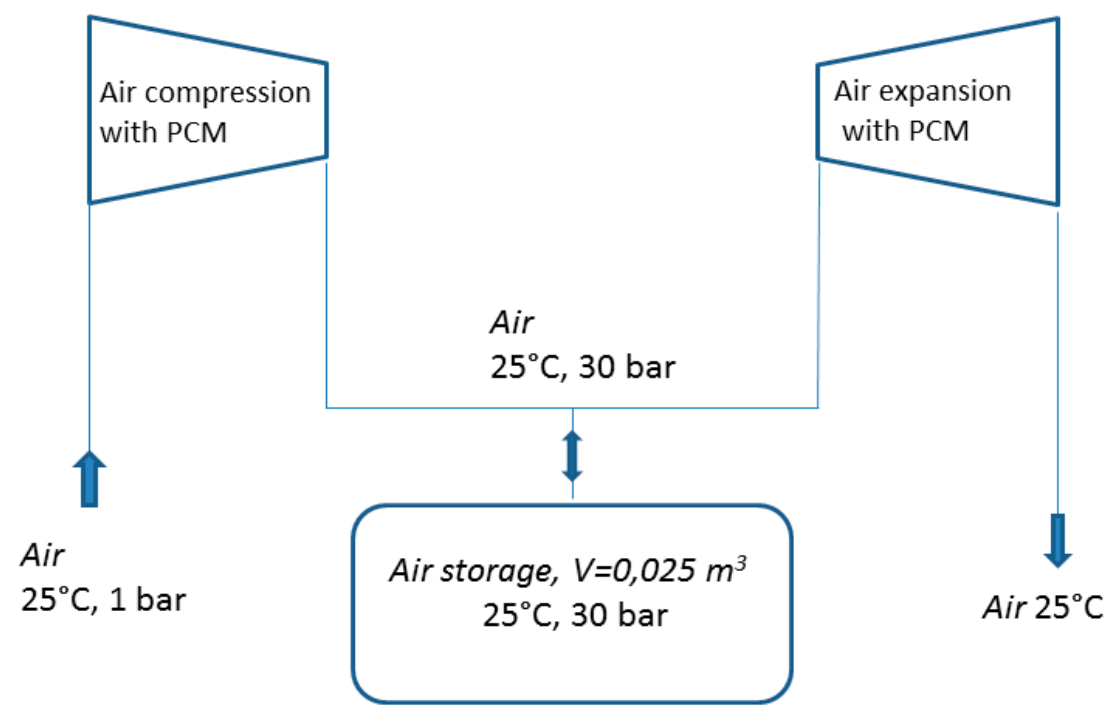

Figure 3. Scheme of isothermal compressed air energy storage (CAES) concept.

\section{Results and Discussion}

Experimental runs were carried out for testing the effect of PCM on air expansion. A first set was carried out with an initial internal pressure of $2 \mathrm{MPa}$ while a second set of experiments was carried out with an initial internal pressure of $3 \mathrm{MPa}$. The measured relative humidity was equal to $50 \%$. Table 2 summarizes experimental conditions for the tests carried out. Temperature and pressure data were used to calculate specific volume through CoolPack Software. Values of temperature, gauge pressure and specific volume for each experimental run are reported in Table 3.

Table 2. Experimental runs.

\begin{tabular}{cccccccc}
\hline Run & $\begin{array}{c}\text { Pressure } \\
(\mathbf{M P a})\end{array}$ & $\begin{array}{c}\text { Time } \\
(\mathbf{s})\end{array}$ & $\begin{array}{c}\text { PCM } \\
\text { Type }\end{array}$ & $\begin{array}{c}\text { PCM } \\
\text { Volume }(\mathbf{L})\end{array}$ & $\begin{array}{c}\text { Initial } \\
\text { Temperature }\left({ }^{\circ} \mathbf{C}\right)\end{array}$ & $\begin{array}{c}\text { Final } \\
\text { Temperature }\left({ }^{\circ} \mathbf{C}\right)\end{array}$ & $\begin{array}{c}\Delta \mathbf{T} \\
\left({ }^{\circ} \mathbf{C}\right)\end{array}$ \\
\hline 1 & 2 & 20 & RT18HC & 1.12 & 24.0 & 13.0 & 11 \\
2 & 2 & 20 & RT18HC & 1.12 & 23.7 & 11.0 & 12.7 \\
3 & 2 & 20 & - & - & 27.7 & 2.5 & 25.2 \\
4 & 2 & 20 & - & - & 28.4 & 2.9 & 25.5 \\
5 & 3 & 30 & RT21HC & 1.68 & 20.7 & -4.0 & 24.7 \\
6 & 3 & 30 & RT21HC & 1.68 & 22.0 & -8.5 & 30.5 \\
7 & 3 & 30 & RT21HC & 1.12 & 21.9 & -10.2 & 32.1 \\
8 & 3 & 30 & RT21HC & 1.12 & 19.7 & -12.1 & 31.8 \\
9 & 3 & 30 & RT21HC & 0.56 & 24.3 & -5.2 & 29.5 \\
10 & 3 & 30 & RT21HC & 0.56 & 24.5 & -6.0 & 30.5 \\
11 & 3 & 30 & - & - & 16.6 & -18.2 & 34.8 \\
\hline
\end{tabular}

In accordance with temperature differences found in Run 3, Run 4 and Run 11, the theoretical quantity of PCM necessary to obtain isothermal expansions was calculated through Equation (1):

$$
m_{P C M}=\frac{m_{\text {air }} \cdot c_{P a i r} \cdot \Delta T_{\text {air }}}{C_{P C M}}
$$


where:

MPCM is the quantity of PCM necessary for isothermal expansion $(\mathrm{kg})$;

mair is air inside the vessel at experimental conditions of pressure and temperature $(\mathrm{kg})$;

cPair is air specific heat capacity $(\mathrm{kJ} / \mathrm{kgK})$;

$\Delta \mathrm{T}_{\text {air }}$ is temperature difference between initial temperature and final temperature $(\mathrm{K})$; and

СРCM is heat storage capacity $(\mathrm{kJ} / \mathrm{kg})$.

Table 3. Values of temperature, pressure and specific volume.

\begin{tabular}{|c|c|c|c|c|c|c|c|c|c|c|c|}
\hline \multicolumn{3}{|c|}{ Run 1} & \multicolumn{3}{|c|}{ Run 2} & \multicolumn{3}{|c|}{ Run 3} & \multicolumn{3}{|c|}{ Run 4} \\
\hline $\begin{array}{c}\mathbf{T} \\
{\left[{ }^{\circ} \mathbf{C}\right]}\end{array}$ & $\begin{array}{c}\mathbf{P} \\
\text { [bar] }\end{array}$ & $\begin{array}{c}\mathbf{v} \\
{\left[\mathrm{m}^{3} / \mathrm{kg}\right]}\end{array}$ & $\begin{array}{c}\mathbf{T} \\
{\left[{ }^{\circ} \mathbf{C}\right]}\end{array}$ & $\begin{array}{c}\mathbf{P} \\
{[\text { bar] }}\end{array}$ & $\begin{array}{c}\mathbf{v} \\
{\left[\mathrm{m}^{3} / \mathrm{kg}\right]}\end{array}$ & $\begin{array}{c}\mathbf{T} \\
{\left[{ }^{\circ} \mathbf{C}\right]}\end{array}$ & $\begin{array}{c}\mathbf{P} \\
{[\text { bar] }}\end{array}$ & $\begin{array}{c}\mathbf{v} \\
{\left[\mathrm{m}^{3} / \mathbf{k g}\right]}\end{array}$ & $\begin{array}{c}\mathbf{T} \\
{\left[{ }^{\circ} \mathbf{C}\right]}\end{array}$ & $\begin{array}{c}P \\
{[\text { bar }]}\end{array}$ & $\begin{array}{c}\mathbf{v} \\
{\left[\mathrm{m}^{3} / \mathrm{kg}\right]}\end{array}$ \\
\hline 24.0 & 19.9 & 0.041 & 23.7 & 19.9 & 0.041 & 27.7 & 19.9 & 0.041 & 28.4 & 20.1 & 0.041 \\
\hline 23.6 & 18.0 & 0.045 & 22.9 & 17.2 & 0.046 & 26.0 & 16.8 & 0.048 & 27.5 & 18.1 & 0.045 \\
\hline 22.5 & 13.7 & 0.057 & 21.4 & 12.9 & 0.061 & 22.7 & 12.3 & 0.063 & 25.3 & 15.4 & 0.052 \\
\hline 20.6 & 10.8 & 0.071 & 19.4 & 10.1 & 0.075 & 18.6 & 9.7 & 0.077 & 21.4 & 11.1 & 0.069 \\
\hline 18.7 & 7.9 & 0.094 & 17.5 & 7.5 & 0.098 & 14.3 & 7.3 & 0.097 & 16.9 & 8.5 & 0.085 \\
\hline 17.2 & 5.7 & 0.124 & 15.9 & 5.3 & 0.131 & 10.7 & 5.5 & 0.122 & 13.0 & 6.4 & 0.107 \\
\hline 15.8 & 4.0 & 0.166 & 14.5 & 3.7 & 0.175 & 6.9 & 3.5 & 0.172 & 10.2 & 5.0 & 0.131 \\
\hline 14.8 & 2.6 & 0.229 & 13.3 & 2.4 & 0.242 & 5.1 & 2.4 & 0.226 & 8.3 & 4.1 & 0.152 \\
\hline 13.9 & 1.5 & 0.329 & 12.4 & 1.5 & 0.328 & 4.5 & 1.9 & 0.264 & 5.5 & 2.3 & 0.233 \\
\hline 13.4 & 0.6 & 0.514 & 11.7 & 0.6 & 0.511 & 3.7 & 1.1 & 0.364 & 4.4 & 1.3 & 0.332 \\
\hline 13.0 & 0.0 & 0.821 & 11.0 & 0.0 & 0.815 & 2.5 & 0.0 & 0.761 & 2.9 & 0.0 & 0.760 \\
\hline \multicolumn{3}{|c|}{ Run 5} & \multicolumn{3}{|c|}{ Run 6} & \multicolumn{3}{|c|}{ Run 7} & \multicolumn{3}{|c|}{ Run 8} \\
\hline $\begin{array}{c}\mathbf{T} \\
{\left[{ }^{\circ} \mathbf{C}\right]}\end{array}$ & $\begin{array}{c}\mathbf{P} \\
{[\text { bar] }}\end{array}$ & $\begin{array}{c}\mathbf{v} \\
{\left[\mathbf{m}^{3} / \mathbf{k g}\right]}\end{array}$ & $\begin{array}{c}\mathbf{T} \\
{\left[{ }^{\circ} \mathbf{C}\right]}\end{array}$ & $\begin{array}{c}\mathbf{P} \\
{[\text { bar] }}\end{array}$ & $\begin{array}{c}\mathbf{v} \\
{\left[\mathbf{m}^{3} / \mathbf{k g}\right]}\end{array}$ & $\begin{array}{c}\mathbf{T} \\
{\left[{ }^{\circ} \mathbf{C}\right]}\end{array}$ & $\begin{array}{c}\mathbf{P} \\
{[\text { bar] }}\end{array}$ & $\begin{array}{c}\mathbf{v} \\
{\left[\mathbf{m}^{3} / \mathbf{k g}\right]}\end{array}$ & $\begin{array}{c}\mathbf{T} \\
{\left[{ }^{\circ} \mathbf{C}\right]}\end{array}$ & $\begin{array}{c}\mathbf{P} \\
{[\mathrm{bar}]}\end{array}$ & $\begin{array}{c}\mathbf{v} \\
{\left[\mathbf{m}^{3} / \mathbf{k g}\right]}\end{array}$ \\
\hline 20.7 & 30.3 & 0.027 & 22.0 & 30.0 & 0.027 & 21.9 & 30.0 & 0.027 & 19.7 & 30.0 & 0.027 \\
\hline 19.5 & 27.1 & 0.030 & 20.9 & 27.1 & 0.030 & 21.3 & 28.1 & 0.029 & 18.7 & 27.4 & 0.030 \\
\hline 18.1 & 25.2 & 0.032 & 19.7 & 25.5 & 0.031 & 20.4 & 26.5 & 0.031 & 16.2 & 24.0 & 0.033 \\
\hline 16.5 & 23.4 & 0.034 & 16.9 & 22.6 & 0.035 & 19.3 & 24.9 & 0.032 & 13.3 & 21.3 & 0.037 \\
\hline 14.9 & 21.9 & 0.036 & 12.2 & 18.6 & 0.041 & 17.9 & 23.4 & 0.034 & 10.2 & 19.1 & 0.040 \\
\hline 11.9 & 19.2 & 0.040 & 10.5 & 17.0 & 0.044 & 16.4 & 22.0 & 0.036 & 7.2 & 16.8 & 0.045 \\
\hline 10.6 & 18.1 & 0.042 & 9.8 & 16.3 & 0.046 & 14.9 & 20.8 & 0.038 & 4.5 & 14.6 & 0.051 \\
\hline 8.9 & 16.6 & 0.045 & 8.6 & 14.9 & 0.050 & 13.4 & 19.7 & 0.040 & 1.8 & 12.4 & 0.059 \\
\hline 5.7 & 13.8 & 0.053 & 7.7 & 13.7 & 0.054 & 12.0 & 18.8 & 0.041 & -0.7 & 10.3 & 0.069 \\
\hline 4.4 & 12.5 & 0.058 & 6.3 & 11.8 & 0.061 & 9.1 & 16.3 & 0.047 & -2.9 & 8.4 & 0.083 \\
\hline 2.3 & 10.5 & 0.067 & 3.6 & 9.0 & 0.078 & 6.1 & 13.8 & 0.054 & -5.0 & 6.2 & 0.107 \\
\hline 1.5 & 9.6 & 0.072 & 2.5 & 8.0 & 0.086 & 3.1 & 11.3 & 0.064 & -6.1 & 5.2 & 0.124 \\
\hline-0.2 & 7.3 & 0.092 & 0.4 & 6.1 & 0.108 & 0.3 & 8.8 & 0.080 & -7.2 & 4.1 & 0.150 \\
\hline-0.6 & 6.6 & 0.100 & -1.2 & 4.9 & 0.129 & -2.2 & 6.7 & 0.101 & -8.5 & 3.1 & 0.185 \\
\hline-1.2 & 2.4 & 0.224 & -4.9 & 2.2 & 0.233 & -5.1 & 4.0 & 0.154 & -9.7 & 2.0 & 0.252 \\
\hline-4.0 & 0.0 & 0.751 & -8.5 & 0.0 & 0.730 & -10.2 & 0.0 & 0.756 & -12.1 & 0.0 & 0.750 \\
\hline
\end{tabular}


Table 3. Cont.

\begin{tabular}{|c|c|c|c|c|c|c|c|c|}
\hline \multicolumn{3}{|c|}{ Run 9} & \multicolumn{3}{|c|}{ Run 10} & \multicolumn{3}{|c|}{ Run 11} \\
\hline $\mathbf{T}\left[{ }^{\circ} \mathbf{C}\right]$ & $\mathbf{P}$ [bar] & $\mathrm{v}\left[\mathrm{m}^{3} / \mathrm{kg}\right]$ & $\mathbf{T}\left[{ }^{\circ} \mathbf{C}\right]$ & $\mathbf{P}$ [bar] & $\mathrm{v}\left[\mathrm{m}^{3} / \mathrm{kg}\right]$ & $\mathbf{T}\left[{ }^{\circ} \mathbf{C}\right]$ & $\mathbf{P}$ [bar] & $\mathrm{v}\left[\mathrm{m}^{3} / \mathrm{kg}\right]$ \\
\hline 24.3 & 29.9 & 0.028 & 24.5 & 30.0 & 0.028 & 16.6 & 30.0 & 0.026 \\
\hline 24.0 & 28.9 & 0.029 & 24.3 & 29.3 & 0.028 & 16.0 & 26.1 & 0.030 \\
\hline 23.1 & 27.1 & 0.030 & 24.0 & 28.3 & 0.029 & 12.5 & 21.0 & 0.037 \\
\hline 20.4 & 22.4 & 0.036 & 22.8 & 26.3 & 0.031 & 7.5 & 16.3 & 0.046 \\
\hline 16.8 & 18.3 & 0.043 & 21.4 & 24.4 & 0.033 & 2.2 & 11.9 & 0.059 \\
\hline 13.0 & 15.3 & 0.050 & 18.8 & 20.6 & 0.039 & -2.5 & 10.0 & 0.068 \\
\hline 9.5 & 12.8 & 0.059 & 15.2 & 16.7 & 0.047 & -4.6 & 8.9 & 0.078 \\
\hline 6.5 & 10.8 & 0.068 & 11.5 & 13.9 & 0.055 & -6.8 & 7.7 & 0.084 \\
\hline 4.2 & 9.1 & 0.079 & 8.1 & 11.6 & 0.064 & -8.8 & 6.6 & 0.100 \\
\hline 2.5 & 7.6 & 0.092 & 5.3 & 9.8 & 0.074 & -10.9 & 5.5 & 0.110 \\
\hline 1.2 & 6.2 & 0.109 & 3.3 & 8.2 & 0.086 & -12.6 & 4.6 & 0.134 \\
\hline 0.3 & 5.1 & 0.129 & 2.3 & 7.2 & 0.096 & -14.3 & 3.7 & 0.149 \\
\hline-0.2 & 4.3 & 0.148 & 0.3 & 5.2 & 0.127 & -15.3 & 3.0 & 0.185 \\
\hline-1.5 & 2.9 & 0.200 & -2.2 & 3.3 & 0.181 & -16.4 & 2.3 & 0.210 \\
\hline-3.0 & 1.7 & 0.287 & -3.3 & 1.8 & 0.277 & -17.3 & 1.3 & 0.319 \\
\hline-5.2 & 0.0 & 0.771 & -6.0 & 0.0 & 0.768 & -18.2 & 0.2 & 0.576 \\
\hline \multicolumn{3}{|c|}{ Run 12} & \multicolumn{3}{|c|}{ Run 13} & \multicolumn{3}{|c|}{ Run 14} \\
\hline $\mathbf{T}\left[{ }^{\circ} \mathbf{C}\right]$ & $\mathbf{P}$ [bar] & $\mathrm{v}\left[\mathrm{m}^{3} / \mathrm{kg}\right]$ & $\mathbf{T}\left[{ }^{\circ} \mathbf{C}\right]$ & $\mathbf{P}$ [bar] & $\mathrm{v}\left[\mathrm{m}^{3} / \mathrm{kg}\right]$ & $\mathbf{T}\left[{ }^{\circ} \mathbf{C}\right]$ & $\mathbf{P}$ [bar] & $\mathrm{v}\left[\mathrm{m}^{3} / \mathrm{kg}\right]$ \\
\hline 16.6 & 30.0 & 0.026 & 24.8 & 30.0 & 0.027 & 23.8 & 30.0 & 0.027 \\
\hline 16.5 & 29.7 & 0.027 & 24.0 & 26.8 & 0.030 & 23.1 & 27.9 & 0.029 \\
\hline 14.7 & 22.2 & 0.035 & 19.7 & 17.7 & 0.044 & 20.0 & 21.0 & 0.038 \\
\hline 9.6 & 15.2 & 0.049 & 13.6 & 12.8 & 0.058 & 14.3 & 13.1 & 0.057 \\
\hline 3.5 & 11.6 & 0.061 & 7.0 & 10.3 & 0.068 & 8.5 & 10.9 & 0.065 \\
\hline-2.5 & 7.9 & 0.084 & 1.5 & 7.5 & 0.088 & 3.5 & 7.0 & 0.094 \\
\hline-7.4 & 5.8 & 0.107 & -2.6 & 5.2 & 0.118 & 0.3 & 5.1 & 0.122 \\
\hline-11.0 & 3.9 & 0.146 & -5.6 & 3.4 & 0.164 & -2.2 & 3.3 & 0.170 \\
\hline-13.4 & 2.3 & 0.214 & -7.5 & 1.9 & 0.247 & -4.0 & 1.8 & 0.259 \\
\hline-14.9 & 1.0 & 0.351 & -8.5 & 0.8 & 0.397 & -5.5 & 0.6 & 0.450 \\
\hline-15.7 & 0.1 & 0.637 & -8.9 & 0.0 & 0.715 & -6.4 & 0.0 & 0.716 \\
\hline
\end{tabular}

For 30-bar expansion, calculated PCM amount is equal to $0.13 \mathrm{~kg}$, corresponding to $0.18 \mathrm{~L}$, while for 20-bar expansion, calculated PCM amount is equal to $0.07 \mathrm{~kg}$, corresponding to $0.08 \mathrm{~L}$.

Considering that PCM is characterized by a very low thermal diffusivity equal to $1.298 \times 10^{-7} \mathrm{~m}^{2} / \mathrm{s}$, interfacial area between air and PCM is the crucial factor during heat transfer. To increase it, it was decided to put several packets oversizing PCM volumes. Indeed, PCM encapsulation plays a significant role in the development of the technology and this is an aspect that is going to be investigated in the future stages of the research.

Passing from $0.56 \mathrm{~L}$ to $1.68 \mathrm{~L}$ of PCM, air amount inside the vessel decreases. In order to reproduce the same heat transfer conditions, the expansion time and the downloading velocity were maintained the same through all the tests. To do so, the airflow during the expansion was controlled. Maximum variation of airflow values was $5 \%$. 
Profiles of internal pressure and temperature for Run 1, Run 3, Run 5 and Run 11 in Table 2 are shown in Figure 4. In particular, internal temperature is calculated as the average of the two temperature values measured by two thermocouples in two different positions.

Data in Table 2 and profiles in Figure 4 show that in presence of PCM, temperature decrease during air expansion is leveled off and temperature difference at the end of the expansion is lower than that without PCMs. With regard to experimental conditions, experimental runs in Table 2 can be divided in two sets. The first set (Run 1-Run 4) was carried out with a pressure of $2 \mathrm{MPa}$ (20 bar) and an expansion time of $20 \mathrm{~s}$. Temperature difference is equal to $11.0^{\circ} \mathrm{C}$ for Run 1 and $12.7^{\circ} \mathrm{C}$ for Run 2 , while in Run 3 and Run 4 it is equal to $25.2^{\circ} \mathrm{C}$ and $25.5^{\circ} \mathrm{C}$, respectively. The second set (Run 5-Run 11) was carried out with a pressure of $3 \mathrm{MPa}(30 \mathrm{bar})$ and an expansion time of $30 \mathrm{~s}$, varying also the amount of PCM put inside the vessel (from 6 to 2 packets). Without PCM, in Run 11 air temperature drops off to a final value of $-18.2{ }^{\circ} \mathrm{C}$ with a $\Delta \mathrm{T}$ of $34.8{ }^{\circ} \mathrm{C}$, while with the use of PCM it reaches $24.7{ }^{\circ} \mathrm{C}$ in Run 5 with six packets. Apart from Run 5, temperature differences with PCM are in the range from $29.5^{\circ} \mathrm{C}$ to $32.1^{\circ} \mathrm{C}$.
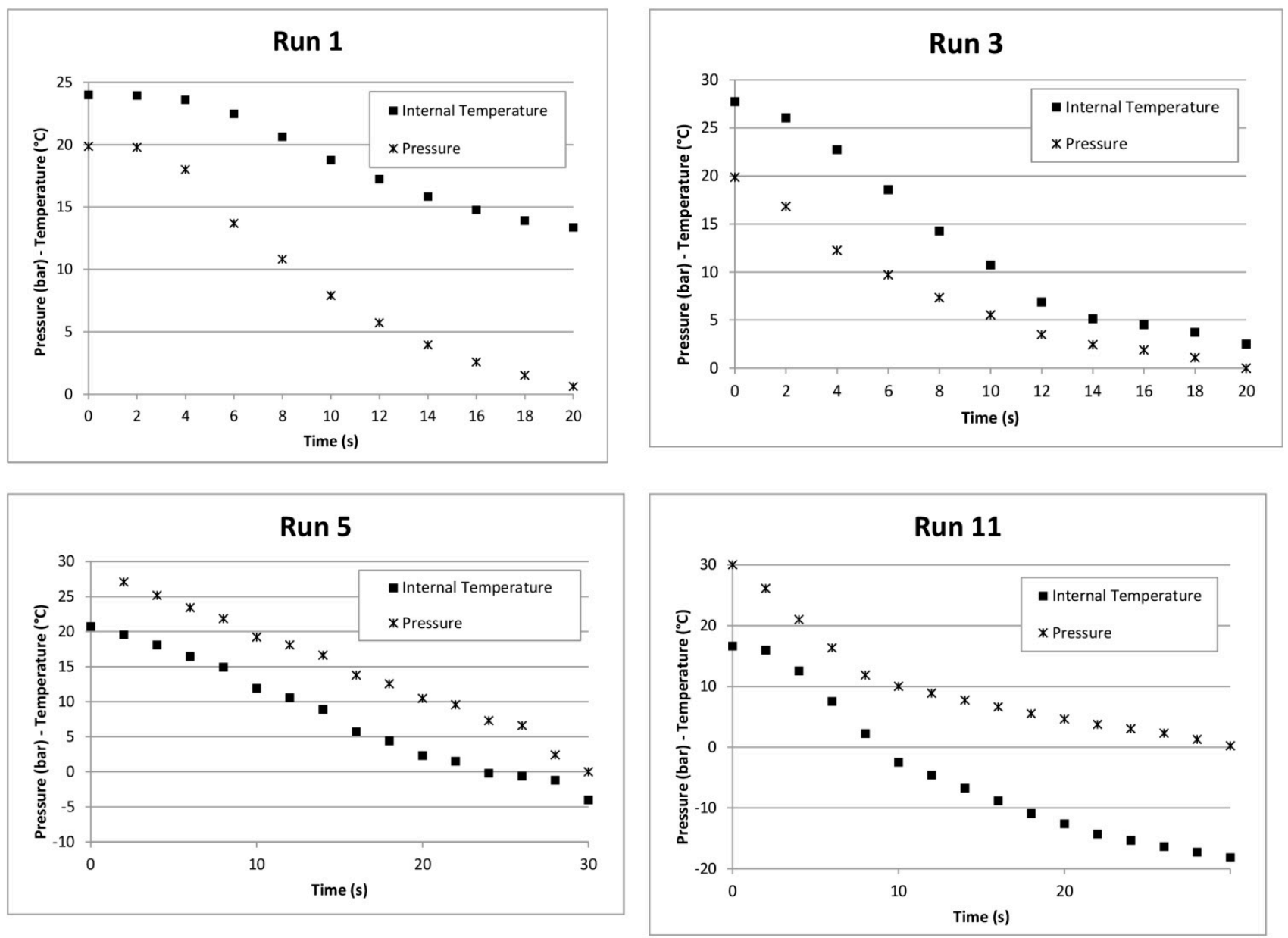

Figure 4. Temperature and pressure profiles.

Data about temperature, pressure and specific volume were processed to build for each experimental run the $\mathrm{P}-\mathrm{v}$ curve and compare it with the adiabatic and isothermal curves. Adiabatic and isothermal curves were depicted in accordance to Equations (2) and (3), respectively: 


$$
\begin{gathered}
P=\frac{k}{v^{\gamma}} \\
P=\frac{R \cdot T}{v}
\end{gathered}
$$

where:

$\mathrm{P}$ is pressure;

$\mathrm{v}$ is the specific volume;

$\mathrm{k}$ is adiabatic constant;

$\gamma$ is the adiabatic index calculated as the ratio of the heat capacity at constant pressure to heat capacity at constant volume;

$\mathrm{R}$ is gas constant; and

$\mathrm{T}$ is internal temperature equal to $293 \mathrm{~K}$.

P-v diagrams for 20-bar expansions are depicted in Figure 5 while P-v diagrams for 30-bar expansions in Figure 6. On y-axis absolute pressure values are reported.

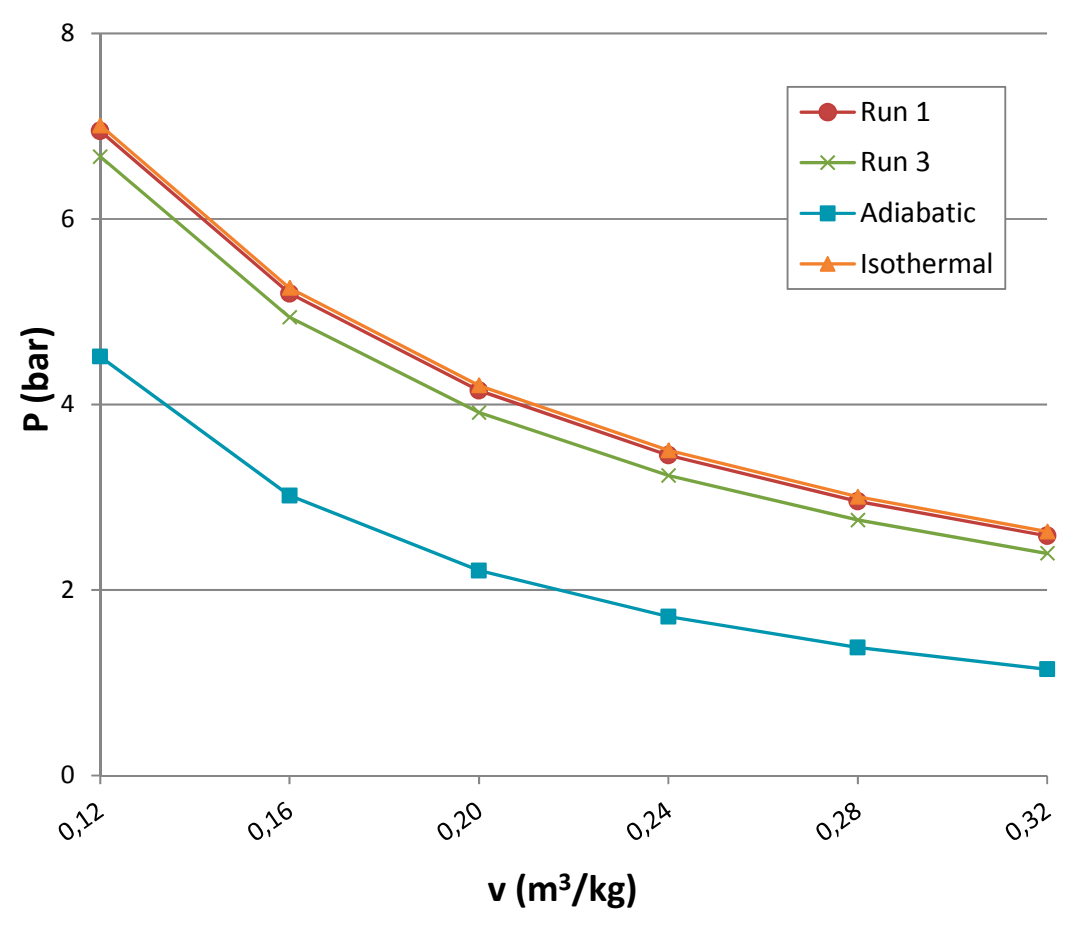

Figure 5. P-v curves for the first set of experimental runs.

As can be seen from Figure 5, Run 1 with PCM is characterized by a P-v curve that resembles quite well the isotherm. Run 3 without PCM instead has a P-v curve that is positioned between the adiabatic and the isotherm.

Figure 6 shows P-v diagrams of Run 5, Run 7, Run 10 and Run 11 compared to adiabatic and isothermal curves for a 30-bar expansion. Run 11 without PCM has a P-v curve that is the most distant from the isothermal. The use of PCM in Run 5, Run 7 and Run 10 instead allows obtaining curves that approach the isothermal. 


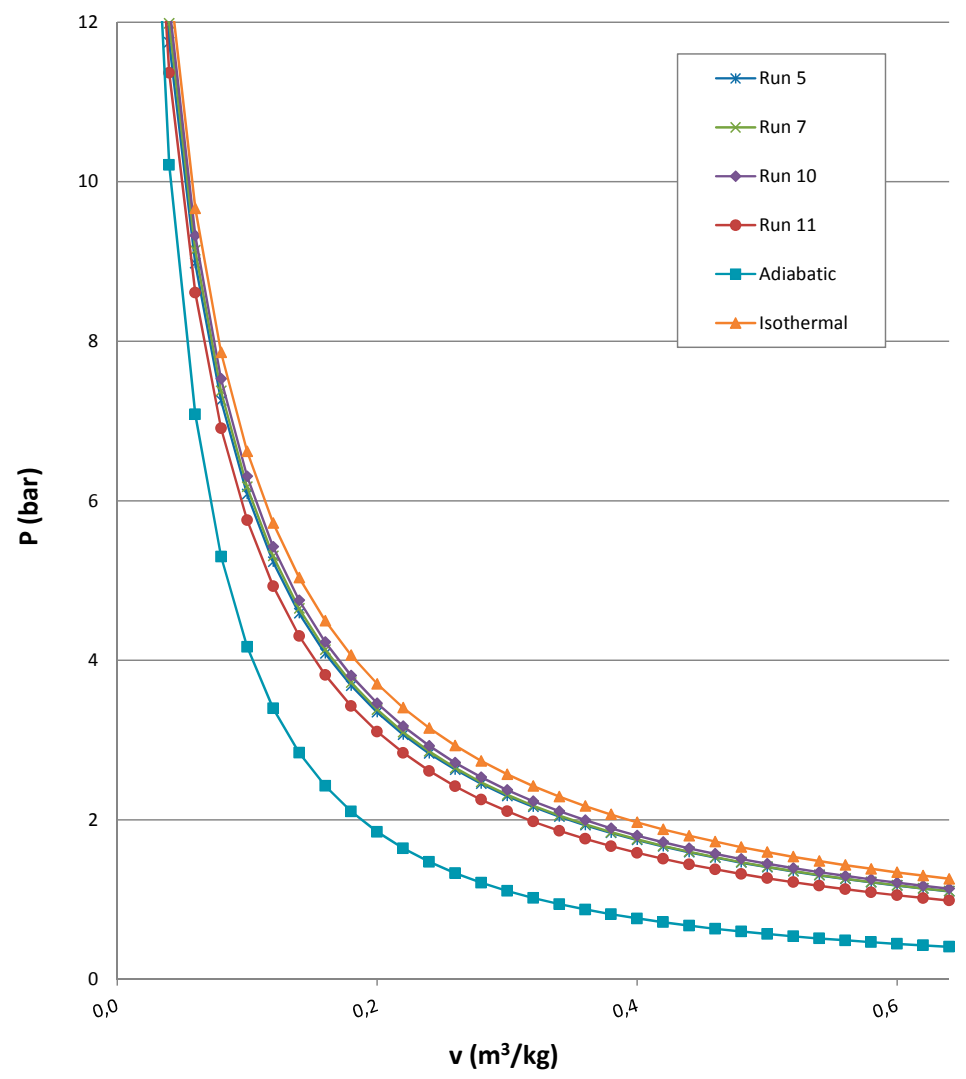

Figure 6. P-v curves for the second set of experimental runs.

Benefits can be evaluated through the calculation of the obtainable expansion work. The amount of expansion work for each experimental run is shown in Table 4.

Table 4. Expansion work.

\begin{tabular}{ccccccccc}
\hline \multicolumn{7}{c}{ Pressure 2 MPa and Expansion Time 20 s } \\
\hline \multicolumn{1}{c}{ Run 1 } & Run 2 & Run 3 & Run 4 & Isothermal \\
\hline Expansion work (J/kg) & 31.74 & 31.47 & 30.23 & 30.13 & 32.09 \\
\hline Pressure 3 MPa and Expansion Time 30 s & & & \\
\hline & Run 5 & Run 6 & Run 7 & Run 8 & Run 9 & Run 10 & Run 11 & Isothermal \\
\hline Expansion work (J/kg) & 28.21 & 28.13 & 28.67 & 28.41 & 29.16 & 29.27 & 26.87 & 30.57 \\
\hline
\end{tabular}

Comparing works obtained from both 20-bar and 30-bar expansions with isothermal work that is the maximum work obtainable from an expansion, it can be noted that the use of PCM has a positive effect in approaching the maximum value. In particular, an increase of 5.4\% for Run 1 and $4.5 \%$ for Run 2 was obtained for 20-bar expansions. In case of 30-bar expansion process, instead, an improvement of $8.9 \%$ is reached as shown in Table 5 .

Table 5. Increase in the expansion work with use of PCM.

\begin{tabular}{cccccccc}
\hline \multicolumn{7}{c}{ Increase in the Expansion Work (\%) } \\
\hline Pressure 2 MPa & \multicolumn{5}{c}{ Pressure 3 MPa } \\
\hline Run 1 & Run 2 & Run 5 & Run 6 & Run 7 & Run 8 & Run 9 & Run 10 \\
\hline 5.4 & 4.5 & 5.0 & 4.7 & 6.7 & 5.7 & 8.5 & 8.9 \\
\hline
\end{tabular}


Comparing Run 1 and Run 2 with Run 7 and Run 8, carried out with the same amount of PCM but with different initial pressures, it is possible to note that PCMs have a more important effect when expansion ratio is higher. In addition, higher improvements were obtained in Run 9 and Run 10 with the lowest amount of PCM (two packets). It suggests that expansion process is affected by the amount of PCM used. This is due mainly to heat capacity phenomena that increase with high amount of materials, causing an incomplete phase transition with consequent lower thermal storage.

\section{Conclusions}

In this paper, paraffin-based phase change materials (PCM) were used in air expansion tests in order to resemble isothermal conditions. Isothermal expansion is one of the stages of Isothermal CAES systems, which represent an emerging high-efficiency technology for electrical energy storage.

Experimental investigation was carried out in a high-pressure vessel pressurized by an air compressor. The experimental facility is located at Terni Applied Physics Laboratory of the University of Perugia. Results show that in presence of PCM near isothermal expansion conditions occur and they affect positively the value of the obtainable expansion work with a maximum increase of $8.9 \%$. If PCM-based isothermal expansion is applied in a CAES system, the overall efficiency of the process could be thus increased considerably.

\section{Author Contributions}

Beatrice Castellani designed and performed the research and wrote the paper. Andrea Presciutti performed research and wrote the paper. Mirko Filipponi and Andrea Nicolini analyzed data. Federico Rossi designed and supervised all steps of the research. All authors read and approved the final manuscript.

\section{Conflicts of Interest}

The authors declare no conflict of interest.

\section{References}

1. Kjarstad, J.; Johnsson, F. Fossil Fuels: Climate Change and Security of Supply. Int. J. Sustain. Water Environ. Syst. 2012, 4, 79-87.

2. Serra, L.M.; Lozano, M.; Ramos, J.; Ensinas, A.V.; Nebra, S.A. Polygeneration and efficient use of natural resources. Energy 2009, 34, 575-586.

3. Lund, H.; Salgi, G. The role of compressed air energy storage in future sustainable energy systems. Energy Convers. Manag. 2009, 50, 1172-1179.

4. Kim, Y.M.; Favrat, D. Energy and exergy analysis of a micro-compressed air energy storage and air cycle heating and cooling system. Energy 2010, 35, 213-220.

5. Ippolito, M.G.; di Silvestre, M.L.; Riva Sanseverino, E.; Zizzo, G.; Graditi, G. Multiobjective optimized management of electrical energy storage systems in an islanded network with renewable energy sources under different design scenarios. Energy 2014, 68, 648-662. 
6. Rubio-Maya, C.; Uche-Marcuello, J.; Martínez-Gracia, A.; Bayod-Rújula, A. Design optimization of a polygeneration plant fuelled by natural gas and renewable energy sources. Appl. Energy 2011, $88,449-457$.

7. International Electrotechnical Commission IEC (Electrical Energy Storage Project Team). Electrical Energy Storage; IEC: Geneva, Switzerland, 2011.

8. Rossi, F.; Nicolini, A. Experimental Investigation on a Novel Electrolyte Configuration for Cylindrical Molten Carbonate Fuel Cells. J. Fuel Cell Sci. Technol. 2011, doi:10.1115/1.4003773.

9. Rossi, F.; Nicolini, A. A Cylindrical Small Size Molten Carbonate Fuel Cell: Experimental Investigation on Materials and Improving Performance Solutions. Fuel Cells 2009, 9, 170-177.

10. Cotana, F.; Filipponi, M.; Castellani, B. A Cylindrical Molten Carbonate Fuel Cell Supplied with Landfill Biogas. Appl. Mech. Mater. 2013, 392, 512-516.

11. Castellani, B.; Giuliobello, M.; Morini, E.; Filipponi, M.; Nicolini, A.; di Giovanna, L.; Cotana, F.; Rossi, F. Methane production as solar energy storage: Energy and process evaluations. In Proceedings of the 14th CIRIAF National Congress, Energy, Environment and Sustainable Development, Perugia, Italy, 4-5 April 2014.

12. Castellani, B.; Morini, E.; Filipponi, M.; Nicolini, A.; Palombo, M.; Cotana, F.; Rossi, F. Clathrate Hydrates for Thermal Energy Storage in Buildings: Overview of Proper Hydrate-Forming Compounds. Sustainability 2014, 6, 6815-6829.

13. Castellani, B.; Rossi, F.; Filipponi, M.; Nicolini, A. Hydrate-based removal of carbon dioxide and hydrogen sulphide from biogas mixtures: Experimental investigation and energy evaluations. Biomass Bioenergy 2014, 70, 330-338.

14. Brinchi, L.; Castellani, B.; Rossi, F.; Cotana, F.; Morini, E.; Nicolini, A.; Filipponi, M. Experimental investigations on scaled-up methane hydrate production with surfactant promotion: energy considerations. J. Pet. Sci. Eng. 2014, 120, 187-193.

15. International Energy Agency (IEA). Technology Roadmap: Energy Storage; IEA: Paris, France, 2014.

16. Radgen, P. 30 Years Compressed Air Energy Storage Plant Huntorf-Experiences and Outlook. In Proceedings of the 3rd International Renewable Energy Storage Conference, Berlin, Germany, 24-25 November 2008.

17. Succar, S.; Williams, R.H. Compressed Air Energy Storage: Theory, Resources, and Applications for Wind Power; Technical Report; Princeton University: Princeton, NJ, USA, 2008.

18. Bullough, C. Advanced Adiabatic Compressed Air Energy Storage for the Integration of Wind Energy. In Proceedings of the European Wind Energy Conference and Exhibition, London, UK, 22-25 November 2004.

19. RWE. ADELE-Adiabatic compressed-air energy storage (CAES) for electricity supply. Available online: http://www.rwe.com (accessed on 14 March 2015).

20. Sustainx. Isothermal CAES Technology. Available online: http://www.sustainx.com/technologyisothermal-caes.htm (accessed on 14 March 2015). 
21. Kim, Y.M.; Lee, J.H.; Kim, S.J.; Favrat, D. Potential and Evolution of Compressed Air Energy Storage: Energy and Exergy Analyses. Entropy 2012, 14, 1501-1521.

(C) 2015 by the authors; licensee MDPI, Basel, Switzerland. This article is an open access article distributed under the terms and conditions of the Creative Commons Attribution license (http://creativecommons.org/licenses/by/4.0/). 